\title{
Pemisahan Selulosa dari Lignin Serat Tandan Kosong Kelapa Sawit dengan Proses Alkalisasi untuk Penguat Bahan Komposit Penyerap Suara
}

\author{
M. Aditya Pradana, Hosta Ardhyananta, dan Moh. Farid \\ Departemen Teknik Material, Fakultas Teknologi Industri, Institut Teknologi Sepuluh Nopember (ITS) \\ Jl. Arief Rahman Hakim, Surabaya 60111 Indonesia \\ e-mail:mofaredo@gmail.com
}

\begin{abstract}
Abstrak-Komposit merupakan salah satu material yang dikembangkan sebagai material penyerap suara. Sebelumnya sudah diteliti mengenai penguat dalam komposit penyerap suara menggunakan serat tandan kosong kelapa sawit. Akan tetapi, penelitian sebelumnya masih dilakukan penelitian untuk prosesnya dan belum diaplikasikan untuk penguat komposit penyerap suara. Sehingga dibuatlah penelitian yang bertujuan untuk mengetahui pengaruh proses alkalisasi pada serat tandan kosong kelapa sawit terutama pada pemisahan selulosa dari lignin serat tersebut. Penelitian ini menggunakan $\mathrm{NaOH} 2 \%$ sebagai pelarut pada proses alkalisasi serat tandan kosong kelapa sawit. Pengujian yang dilakukan yaitu uji FTIR pada serat tandan kosong kelapa sawit tanpa perlakuan dan dengan perlakuan alkalisasi. hasil uji FTIR menunjukkan serat tandan kosong kelapa sawit dialkalisasi secara kurang optimal dengan masih menyisakan sebagian kadar lignin yang ditunjukkan dengan masih terdapatnya peak gugus aromatik $\mathrm{C}=\mathrm{C}$ pada rentang $1200-1300 \mathrm{~cm}^{-1}$.
\end{abstract}

Kata Kunci- FTIR, Lignin, Proses Alkalisasi, Selulosa, Serat Tandan Kosong Kelapa Sawit.

\section{PENDAHULUAN}

$\mathrm{M}$ ATERIAL komposit merupakan area penelitian yang sangat luas dan telah menjadi solusi untuk banyak permasalahan. Pada perkembangannya, saat ini telah dikembangkan berbagai material komposit dari serat alam yang digunakan sebagai bahan penyerap suara. Salah satunya adalah material komposit berpenguat serat bambu untuk absorpsi suara. Terdapat kenaikan secara signifikan nilai koefisien absorbsi suara pada frekuensi $1000 \mathrm{~Hz}$ sebesar 0.972 untuk material poliester berpenguat serat bambu $[1,2]$.

Untuk penelitian ini digunakan serat tandan kosong kelapa sawit yang merupakan produk sampingan dari industri pengolahan minyak kelapa sawit. Indonesia dan Malaysia merupakan penghasil kelapa sawit terbesar di dunia. Akan tetapi, dalam produksi minyak kelapa sawit menghasilkan limbah yaitu berupa tandan kosong sebesar 1.1 ton pada setiap 1 ton minyak yang terproduksi [3].

Di Indonesia, tandan kosong kelapa sawit dimanfaatkan sebagai bahan pulp kertas, papan serat dan pengisi volume bahan furniture. Tandan kosong kelapa sawit yang dimanfaatkan memiliki berbagai karakteristik yang perlu dilakukan penelitian oleh karena itu diperlukan adanya penelitian yang mengkaji mengenai karakteristik serat tandan kosong kelapa sawit. Pengolahan serat tandan kosong kelapa sawit dimulai dari proses pengambilan sampel tandan kosong kelapa sawit, sampel tandan kosong kelapa sawit kemudian ditimbang beratnya sebelum diberikan perlakuan perebusan dan pengukusan, tandan kosong kelapa sawit dicuci dengan air bersih agar kotoran-kotoran yang tidak diinginkan berkurang [3]

Salah satu solusi pemanfaatannya yaitu menjadikannya sebagai bahan pengisi (filler) pengganti kayu dalam proses pembuatan papan komposit plastik. Kadar selulosa yang tinggi sehingga memiliki sifat mekanik yang baik seperti nilai kekuatan tarik sebesar 100-400 MPa, modulus elastisitas sebesar 1-9 GPa, serta regangan total sebesar 9-18 \% [4]. Maka sifat serat kelapa sawit membuatnya sesuai untuk aplikasi komposit. Satu-satunya penggunaan material kaya selulosa yang sangat sering saat ini adalah sebagai bahan bakar boiler dan dalam pembuatan pupuk kalium. Sampai saat ini, tidak ada kerja yang sistematis telah dilakukan untuk mengevaluasi sifat morfologi dan fisik dari serat kelapa sawit. Serat TKKS memiliki kandungan lignin sebesar $19 \%$, selulosa sebesar 65\%, dan ash sebesar 2\% [4].

Lignin $\left(\mathrm{C}_{9} \mathrm{H}_{10} \mathrm{O}_{2}\left(\mathrm{OCH}_{3}\right)\right.$ n) adalah salah satu komponen penyusun tanaman yang bersama dengan selulosa dan bahanbahan serat lainnya membentuk bagian struktural dan sel tumbuhan. Lignin, yang menyusun hingga 10- 25\% dari biomassa lignoselulosa, adalah polimer alam yang kedua paling melimpah. Lignin tidak larut dalam air dan stabil di alam dan bertindak sebagai "lem" yang menghubungkan selulosa dan hemi-selulosa [5].

Selulosa merupakan suatu polisakarida yang mempunyai formula umum seperti pati $\left(\mathrm{C}_{6} \mathrm{H}_{10} \mathrm{O}_{5}\right) \mathrm{n}$. Sebagain besar selulosa terdapat pada dinding sel dan bagian-bagian berkayu dari tumbuhan-tumbuhan [6]. Selulosa merupakan substansi yang tidak larut dalam air yang terdapat di dalam dinding sel tanaman terutama dari bagian batang, tangkai dan semua bagian yang mengandung kayu. Selulosa merupakan homopolisakarid yang mempunyai molekul berbentuk linear [7]. Struktur yang linier menyebabkan selulosa bersifat kristalin dan tidak mudah larut. Selulosa tidak mudah didegradasi secara kimia maupun mekanis. Di alam, biasanya selulosa berasosiasi dengan polisakarida lain seperti hemiselulosa atau lignin membentuk kerangka utama dinding sel tumbuhan [8]. Selulosa memiliki peran dalam memberi kekuatan pada serat itu sendiri [9], dan juga tidak mudah terdegradasi secara kimia maupun mekanis. Selain itu, selulosa juga merupakan bahan yang dapat digunakan untuk aplikasi insulasi termal dan penyerapan suara [10]. 
Keuntungan utama dari penggunaan selulosa sebagai bahan penguat pada matriks polimer yaitu: densitas rendah, tidak mudah terabrasi, kemampuan mengisi tinggi yang menghasilkan sifat kekakuan yang tinggi, mudah didaur ulang, bahannya mudah didapat karena banyak tersedia di alam, dan murah. Akan tetapi serat tandan kosong kelapa sawit dan serat alam lainnya memiliki kekurangan apabila dijadikan penguat dalam komposit. Serat alami bersifat hidofilik sehingga menyebabkan gaya adhesi antara serat dan matriks bernilai rendah. Maka dari itu, untuk mengoptimalkan sifat dari selulosa dan untuk menaikkan gaya adhesi antara serat dengan matriks polimer, dibutuhkan perlakuan baik perlakuan fisik maupun perlakuan kimia. Perlakuan kimia pada serat dapat mengubah struktur fisik maupun struktur kimia dari permukaan serat tersebut. Salah satu proses perlakuan kimia adalah alkalisasi. Alkalisasi merupakan metode yang paling banyak digunakan yang memiliki tujuan untuk menghilangkan kandungan lignin dan minyak yang menutupi permukaan luar seart. Efek yang timbul dari perlakuan alkalisasi adalah berubahnya ikatan hidrogen dalam struktur jaringan serat yang mengakibatkan permukaan serat menjadi kasar. [11]

Pengaruh alkalisasi terhadap kinerja serat daun nanas/komposit Poly Lactic Acid telah ditunjukkan [12]. Didapatkan bahwa perlakuan alkalisasi menyebabkan sifat mekanik komposit menjadi semakin unggul apabila dibandingkan dengan serat yang tanpa diberi perlakuan alkalisasi. Studi ini juga menunjukkan bahwa dengan proses alkalisasi dapat memodifikasi permukaan serat yang secara signifikan memberi kontribusi dalam memperbaiki sifat antarmuka dari biokomposit.

Proses alkalisasi adalah salah satu metode yang digunakan untuk memberikan modifikasi permukaan pada serat alam. Proses alkalisasi dilakukan dengan perendaman serat pada larutan alkali $(\mathrm{NaOH})$ dengan perlakuan berbeda pada waktu dan temperatur [13]. Proses alkalisasi akan memunculkan selulosa dan menghilangkan pengotor pada permukaan serat alam seperti lignin dan pektin sehingga dapat meningkatkan sifat mekanik dari serat [14].

Reaksi yang terjadi selama proses alkalisasi berlangsung ditunjukkan pada Gambar 1.

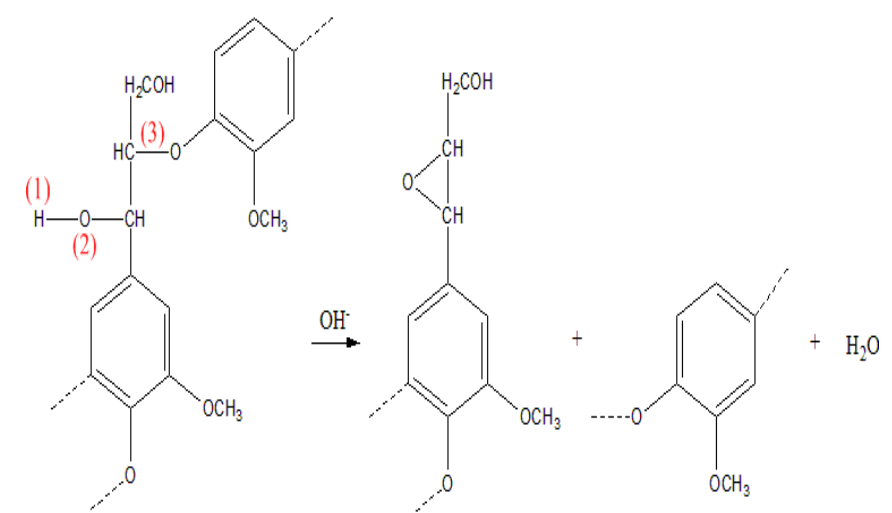

Gambar 1. Reaksi pada Proses Alkalisasi[15]

Gambar 1 menunjukkan pada proses alkalisasi, lignin bereaksi dengan larutan $\mathrm{NaOH}$ yang terdisosiasi menjadi $\mathrm{Na}^{+}$ dan $\mathrm{OH}^{-}$. Ion $\mathrm{OH}^{-}$bereaksi dengan gugus $\mathrm{H}$ pada lignin, kemudian membentuk $\mathrm{H}_{2} \mathrm{O}$. Hal ini menyebabkan gugus $\mathrm{O}$ membentuk radikal bebas dan reaktif dengan $\mathrm{C}$ membentuk cincin epoksi (C-O-C). Sehingga menyebabkan serangkaian gugus melepaskan ikatan pada gugus O. Reaksi menghasilkan dua cincin benzene yang terpisah, dimana masing-masing cincin memiliki gugus $\mathrm{O}$ yang reaktif. Gugus $\mathrm{O}$ reaktif ini bereaksi dengan $\mathrm{Na}^{+}$dan ikut larut dalam larutan basa sehingga lignin hilang apabila dibilas [15].

Oleh karena itu, untuk mengoptimalkan sifat dari selulosa, maka dilakukan proses alkalisasi dengan larutan $\mathrm{NaOH}$ yang bertujuan untuk menghilangkan lignin dan mengurangi diameter dari serat itu sendiri. Dan untuk mengetahui pengaruh proses alkalisasi terhadap perubahan morfologi pada serat dari tandan kosong kelapa sawit dianalisis dengan melakukan pengujian FTIR

\section{METODE PENELITIAN}

\section{A. Material}

Material yang digunakan pada penelitian ini adalah Serat Tandan Kosong Kelapa Sawit yang didapatkan dari perkebunan kelapa sawit didaerah Dumai, Provinsi Riau, Indonesia, $\mathrm{NaOH} 2 \%$ yang diperoleh dari PT. Justus Kimia Raya Surabaya, dan Aquades $\left(\mathrm{H}_{2} \mathrm{O}_{2}\right)$.

\section{B. Preparasi Serat}

Pembuatan serat tandan kosong kelapa sawit diawali dengan penjemuran serat selama \pm 2 hari untuk menghilangkan kelembaban. Setelah itu, serat tandan kosong kelapa dibersihkan dari pengotor dengan air bersih. Kemudian serat dikeringkan dengan oven pada temperatur $90^{\circ}$ C. Setelah bersih dan kering, serat tandan kosong kelapa sawit diperkecil ukurannya dengan menggunakan mesin pencacah organik. Serat tandan kosong kelapa sawit yang sudah dicacah kemudian di-meshing untuk mendapatkan ukuran yang homogen dengan rentang ukuran antara 280 hingga 900 mikron. Perlakuan alkalisasi serat tandan kosong kelapa sawit dilakukan dengan $\mathrm{NaOH} 2 \%$ selama 3 jam pada temperatur $70^{\circ} \mathrm{C}$ menggunakan magnetic stirrer. Pencucian sampel hasil alkalisasi dilakukan dengan aquades sampai pengotor pada permukaan hilang. Kadar air serat tandan kosong kelapa sawit dihilangkan dengan cara di-oven pada temperatur $105^{\circ} \mathrm{C}$ selama 12 jam.

\section{Uji Fourier Transform Infrared(FTIR)}

Pengujian FTIR dilakukan untuk mengetahui ikatan kimia serat tandan kosong kelapa sawit . Ikatan kimia tersebut diindikasikan dengan puncak-puncak yang berbeda. Pengujian ini dilakukan untuk mengetahui ikatan dari serat tandan kosong kelapa sawit serta untuk mengkonfirmasi apakah bahan yang dipakai telah sesuai. Alat uji FTIR yang digunakan ditunjukkan oleh Gambar 2. 


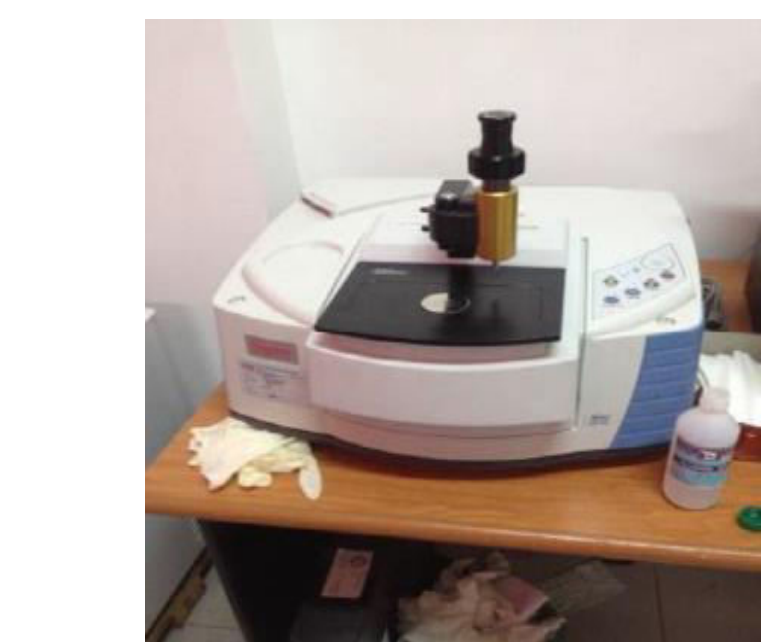

Gambar 2. Alat Uji FTIR

Gambar 2 menunjukkan alat uji FTIR The Nicolet Is10 FTIR Sepctrometer yang digunakan untuk penelitian sehari-hari. The Nicolet Is FT-IR Sepctrometer dapat memberikan kepercayaan tinggi kepada pengguna dalam verifikasi dan identifikasi bahan. Dalam Spesifikasinya, alat uji ini memiliki Beam Splitter $\mathrm{KBr} / \mathrm{Ge}$ mid-infrared yang telah dioptimalkan, dan XT-KBr/Ge yang dapat memperluas jangkauan midinfrared. Laser yang digunakan adalah HeNe. Untuk memenuhi pelanggan The Nicolet Is10 FT-IR Sepctrometer standard ASTM E1421 yang dapat memenuhi standar dari pelanggan dengan patokan ISO/GLP. Alat uji FTIR The Nicolet Is10 FT-IR Sepctrometer memiliki 2 komponen utama yaitu Mid-Infrared dan Tungsten/halogen, dimana kedua komponen tersebut dapat digantikan dengan kompartemen lainnya berdasarkan sampel yang akan diujikan. Daya yang dibutuhkan untuk menjalankan alat uji FTIR The Nicolet Is 10 FT-IR Sepctrometer sebesar 100-240 V 50/60 Hz. Alat ini mampu memecah cahaya sampai pada kedalaman $550 \mathrm{~mm}$. Sumber Infrared yang dipancarkan dari alat ini memiliki 2 tipe, yaitu Mid-Infrared Ever-Glo dan Tungsten/Halogen (dimana kedua komponen tersebut dapat digantikan dari kompartemen lainnya berdasarkan sampel yang akan diujikan). Alat uji FTIR The Nicolet Is10 FT-IR Sepctrometer memiliki Jarak Spectral yang berbeda-beda untuk masing masing komponen. Pada mid-infrared $\mathrm{KBr}$ beam splitter memiliki jarak serapan Infrared berkisar antara $7800-350 \mathrm{~cm}^{-}$ 1. Sedangkan untuk komponen $\mathrm{XT} \mathrm{KBr}$ memiliki daerah serapan Infrared berkisaran antara 11000-375 $\mathrm{cm}^{-1}$. The Nicolet Is10 FT-IR Sepctrometer memiliki spectral resolution yang lebih baik dari 0.4 wavenumbers. Detektor yang digunakan The Nicolet Is 10 FT-IR Sepctrometer adalah Fast recovery deuterated triglycine sulfate (DTGS) (standard); Liquid-nitrogen-cooled mercury cadmium telluride (MCT) (optional) yang dapat menangkap berkas sinar Infrared dari bias yang dipancarkan dari sampel [16].

Adapun cara kerja FTIR seperti berikut ini: Mula - mula zat yang akan diukur diidentifikasi, berupa atom atau molekul. Sinar infra merah yang berperan sebagai sumber sinar dibagi menjadi dua berkas, satu dilewatkan melalui sampel dan yang lain melalui pembanding. Kemudian secara berturut-turut melewati chopper. Setelah melalui prisma atau grating, berkas akan jatuh pada detektor dan diubah menjadi sinyal listrik yang kemudian direkam oleh rekorder. Selanjutnya diperlukan amplifier bila sinyal yang dihasilkan sangat lemah [16].

Standar yang digunakan adalah ASTM E125 dengan sampel yang digunakan dapat dengan mudah diuji FTIR. Scan inframerah yang khas dihasilkan di wilayah pertengahan inframerah dari spektrum cahaya. Daerah pertengahan inframerah adalah 400-4000 $\mathrm{cm}^{-1}$ wavenumbers yang sama dengan panjang gelombang 2,5 sampai 25 mikron(10 -3 mm)

\section{HASIL DAN PEMBAHASAN}

Penelitian ini menggunakan serat tandan kosong kelapa sawit yang dialkalisasi. Proses alkalisasi bertujuan untuk menghilangkan lignin pada serat tandan kosong kelapa sawit.

Serat Tandan Kosong Kelapa Sawit mengandung lignin, hemiselulosa dan selulosa. Gambar 3 menunjukkan hasil FTIR serat tandan kosong kelapa sawit. Tabel 1 menunjukkan daerah serapan infra merah serat tandan kosong kelapa sawit tanpa perlakuan dan dengan perlakuan alkalisasi.

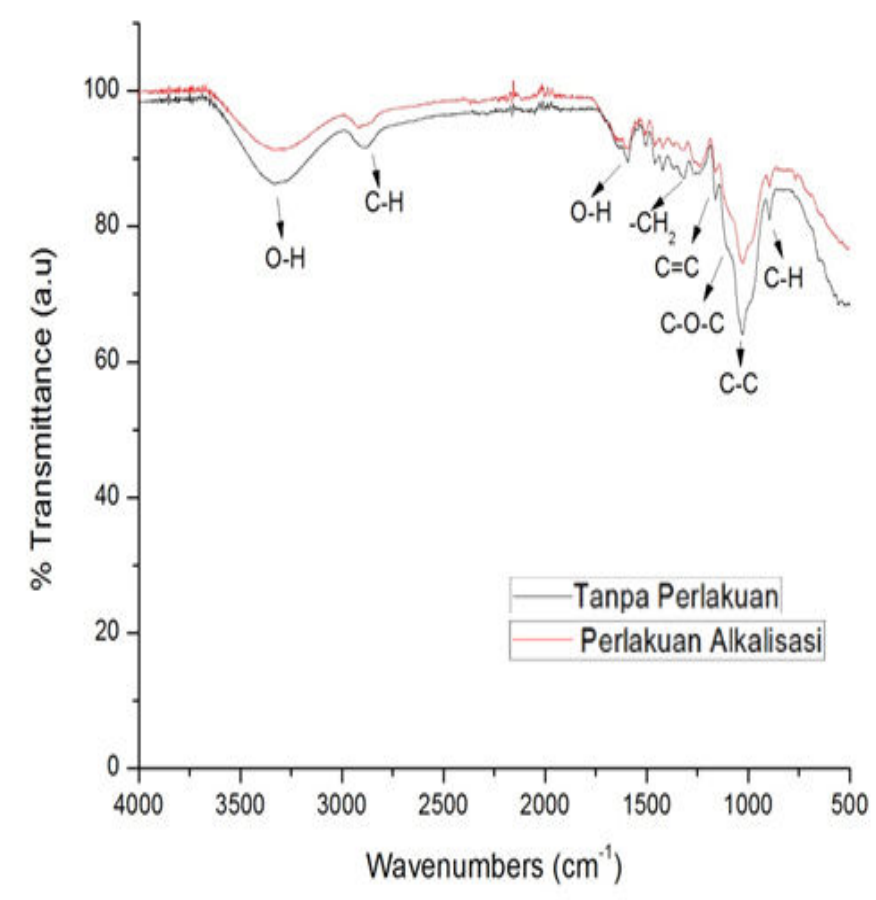

Gambar 3. FTIR Serat TKKS Perlakuan Alkalisasi

Tabel 1.

Daerah Serapan Inframerah Serat TKKS Tanpa Perlakuan dan Alkalisasi

\begin{tabular}{ccc}
\hline \hline $\begin{array}{c}\text { Daerah Serapan }\left(\mathbf{c m}^{-\mathbf{1}}\right) \\
\text { Tanpa } \\
\text { Perlakuan }\end{array}$ & Alkali & Ikatan dan Jenis Gugus Fungsi \\
\hline 3322,84 & 3333,30 & O-H stretching \\
2918,62 & 2884,83 & C-H stretching \\
1593,46 & 1592,74 & O-H deformasi \\
1420,29 & 1420,32 & $-\mathrm{CH}_{2}$ deformasi \\
1238,97 & 1264,50 & C=C cincin aromatik \\
1161,32 & 1161,69 & C-O-C streching \\
1027,49 & 1028,63 & C-C streching \\
895,52 & 895,57 & C-H deformasi \\
\hline \hline
\end{tabular}

Tabel 1 menunjukkan hasil uji FTIR serat tandan kosong kelapa sawit tanpa perlakuan dan perlauan alkali. Serat tandan 
kosong kelapa sawit tanpa perlakuan memiliki ikatan $\mathrm{O}-\mathrm{H}$ streching pada puncak gelombang $3322,84 \mathrm{~cm}^{-1}$, C-H stretching pada $2918,62 \mathrm{~cm}^{-1}$, O-H deformasi pada 1593,46 $\mathrm{cm}^{-1},-\mathrm{CH}_{2}$ deformasi pada $1420,29 \mathrm{~cm}^{-1}, \mathrm{C}=\mathrm{C}$ cincin aromatik pada $1238,97 \mathrm{~cm}^{-1}$, C-O-C stretching pada $1161,32 \mathrm{~cm}^{-1}$, C-C stretcing pada $1027,49 \mathrm{~cm}^{-1}$, dan C-H deformasi pada 895,52 $\mathrm{cm}^{-1}$. Serat tandan kosong kelapa sawit dengan perlakuan alkalisasi ikatan $\mathrm{O}-\mathrm{H}$ streching pada puncak gelombang $3333,30 \mathrm{~cm}^{-1}$, C-H stretching pada $2884,83 \mathrm{~cm}^{-1}, \mathrm{O}-\mathrm{H}$ deformasi pada $1592,74 \mathrm{~cm}^{-1}$, $-\mathrm{CH}_{2}$ deformasi pada 1420,32 $\mathrm{cm}^{-1}, \mathrm{C}=\mathrm{C}$ cincin aromatik pada $1264,50 \mathrm{~cm}^{-1}$, C-O-C stretching pada $1161,69 \mathrm{~cm}^{-1}$, C-C stretcing pada $1028,63 \mathrm{~cm}^{-}$ 1, dan C-H deformasi pada $895,57 \mathrm{~cm}^{-1}$. Pada puncak wavenumber antara 3000 dan $3500 \mathrm{~cm}^{-1}$ mengindikasikan ikatan O-H mengalami peregangan akibat pengaruh alkalisasi. Alkalisasi mengurangi ikatan hidrogen karena gugus hidroksil bereaksi dengan sodium hidroksida yang menyebabkan meningkatnya konsentrasi $-\mathrm{OH}$ jika dibandingkan dengan serat tanpa perlakuan [17]. Ikatan -OH deformasi pada daerah serapan sekitar $1590 \mathrm{~cm}-1$ menunjukkan penyerapan air oleh selulosa [17]. Ikatan C-O-C yang mengalami peregangan didapat pada daerah resapan sekitar $1161 \mathrm{~cm}^{-1}$. Pada puncak sekitar $1027 \mathrm{~cm}^{-1}$ menujukkan ikatan $\mathrm{C}-\mathrm{C}$ yang mengalami peregangan. Puncak pada daerah serapan sekitar $896 \mathrm{~cm}^{-1}$ menujukkan ikatan C-H deformasi [18]. Puncak serapan sekitar $2900 \mathrm{~cm}^{-1}$ menunjukkan peregangan gugus alifatik C$\mathrm{H}$ [18]. Daerah serapan sekitar $1420 \mathrm{~cm}-1$ menunjukkan ikatan $-\mathrm{CH}_{2}$ yang berdeformasi dalam selulosa. Daerah ini menunjukkan area kristalin, dimana daerah serapan akan meningkat seiring dengan proses pemurnian [19]. Lignin ditunjukkan oleh adanya peak pada rentang $1200-1300 \mathrm{~cm}^{-1}$ dengan gugus aromatik $\mathrm{C}=\mathrm{C}$. Pada rentang $1200-1300 \mathrm{~cm}^{-1}$, masih terdapat peak dengan intensitas berkurang yang mengindikasikan perlakuan alkali kurang optimal sehingga tidak menghilangkan lignin seluruhnya namun hanya mengurangi kadar dari lignin [20]. Jadi dapat diambil kesimpulan bahwa hasil uji FTIR menunjukkan serat tandan kosong kelapa sawit dialkalisasi secara kurang optimal dengan masih menyisakan sebagian kadar lignin yang ditunjukkan dengan masih terdapatnya peak pada rentang $1200-1300 \mathrm{~cm}^{-1}$.

\section{KESIMPULAN}

Berdasarkan hasil penelitian dan pembahasan, hasil uji FTIR menunjukkan serat tandan kosong kelapa sawit dialkalisasi secara kurang optimal dengan masih menyisakan sebagian kadar lignin yang ditunjukkan dengan masih terdapatnya peak gugus aromatik $\mathrm{C}=\mathrm{C}$ pada rentang 1200 $1300 \mathrm{~cm}^{-1}$.

\section{UCAPAN TERIMA KASIH}

Penulis mengucapkan terima kasih kepada Program Penelitian Unggulan Perguruan Tinggi, Kemenristekdikti tahun 2017 yang telah mendukung pendanaan dalam penelitian ini.

\section{DAFTAR PUSTAKA}

[1] M. Farid, H. Ardhyananta, V. M. Pratiwi, S. P Wulandari, "Correlation between Frequency and Sound Absorption Coefficient of Polymer Reinforced Natural Fibre". Advanced Materials Research. Vol. 1112, (2015) 329-332.

[2] M. Farid and T. Heriyanto, "Correlation of Normal Incidence Sound Absorbtion Coefficient (NAC) and Random Incidence Sound Absorbtion Coeffitient (RAC) of Polyester/Ramie Fibre Composite Materials". Advance Materials Research. Vol. 789 (2013) 269-273.

[3] Shinoj. "Oil Palm Fiber (OPF) and Its Composites". Industrial Crops and Products. Vol. 33 (2011) 7-22.

[4] MS. Sreekala, Kumaran MG, Thomas S, “ Oil Palm Fibers: Morphology, Chemical Composition, Surface Modification, an Mechanical Properties". J Appl Plym Sci. Vol. 66 (1997) 821-835.

[5] E . Akin D, "Plant Cell Wall Aromatics: influence of degradation of biomass, biofuels, bioproducts, and bio process". Vol. 2 (2008) 288-303

[6] Anggorodi, R. 1994, "Ilmu Makanan Ternak". Jakarta: Gramedia Pustaka Utama.

[7] Albert L. Lehninger, David L. Nelson, dan Michael M. Cox, " Lehninger Principles of Biochemistry". Worth Publishers, New York (2000).

[8] M. T. Holtz apple, "Hemicelluloses". In Encyclopedia of Food Sciences and Nutrition (2003) 3060-3071

[9] A. Wirajaya, "Karakteristik Komposit Sandwich Serat Alami Sebagai Absorber Suara" Tugas Akhir, ITB, Bandung, Indonesia (2007).

[10] P. Lertwattanaruk, A. Suntijitto. "Properties of Natural Fiber Cement Materials Containing Coconut Coir and Oil Palm Fibers for Residential Building Application". Construction and Building Materials 94 (2015) 664-669

[11] O. Faruk, Andrzej K. Bledzki, Hans-Peter Fink, Mohini Sain. "Biocomposites Reinforced with Natural Fibers". Progress in Polymer Science 37 (2012) 1552-1596.

[12] M. S. Huda, L. T. Drzal, A. K. Mohanty, M. Misra. "Effect Of Chemical Modifications of the Pineapple Leaf Fiber Surfaces on the Interfacial and Mechanical Properties of Laminated Biocomposites". Composite Interfaces 15 (2008) 169-91.

[13] Li X, Tabil LG, Panigrahi S, "Chemical Treatments of Natural Fibers for Use in Natural Fiber Reinforced Composites: a review". J Polym Environ. Vol. 15 (2007) 25-33

[14] MA. Fuqua, Huo S, Ulven CA, "Natural Fiber Reinforced Composites" Polym Rev. Vol. 52 (2012) 259-320

[15] Sultoni, Yusuf. Moh. Farid, Alvian T. Wibisono, "Pengaruh Proses Alkali dan Fraksi Massa Serat terhadap Sifat Fisik dan Sifat Mekanik Komposit Polyurethane/Coir Fiber". Tugas Akhir, ITS Surabaya (2017)

[16] Thermo Fisher, Nicolet ${ }^{\mathrm{TM}} i S^{\mathrm{TM}} 10 \quad$ FT-IR Spectrometer, https://www.thermofisher.com/order/catalog/product/IQLAADGAAGF AHDMAPC?SID=srch-srp-IQLAADGAAGFAHDMAPC (Diakses pada 24 Juli 2017).

[17] J. Lojewska, P. Miskowiec, T. Lojewski, L. M. Proniewicz, "Cellulose oxidative and hydrolytic degradation: In situ FTIR approach" Polymer Degradation and Stability 88 (2005) 512-520

[18] B. Shanmugarajah, Peck Loo Kiew, Irene Mei Leng Chew, Thomas Shean Yaw Choong, Khang Wei Tan, "Isolation of Nano Crystalline Cellulose (NCC) from Palm Oil Empty Fruit Bunch (EFB): Preliminary Result on FTIR and DLS Analysis". Chemical Engineering Transactions. Vol. 45 (2015) 1705-1710.

[19] L. Alves, Bruno Medronho, Filipe E. Antunes, Maria P. FernándezGarcía, João Ventura, João P. Araújo, Anabela Romano, Bjorn Lindman. "Unusual Extraction and Characterization of Nanocrystalline Cellulose from Cellulose Derivatives". Journal of Molecular Liquids. Vol. 210 (2015) 106-112.

[20] HAN. Hong c h a n g , "Study of Agro-composite Hemp/Polypropylene: Treatment of Fibers, Morphological and Mechanical Characterization". Mechanical Systems and Materials Universite de Technologie Troyes (2015) 1705-1710. 